\title{
Selected economic factors of the quality of business environment
}

\author{
Martin Cepel \\ Faculty of Economics and Business, \\ Paneuropean University in Bratislava, \\ Slovakia \\ martin.cepel@paneurouni.sk
}

\section{Jaroslav Belas}

Center for Applied Economic Research, Faculty of Management and Economics,

Tomas Bata University in Zlin,

Crech Republic

belas@utb.cr.

\section{Zoltan Rozsa}

Faculty of Social and Economic Relations

Alexander Dubcek University in Trencin

Slovakia

zoltan.rozsa@tnuni.sk

\section{Zdeněk Strnad}

Department of Law, Faculty of Economics, University of South

Bohemia in Ceské Budèjovice

Crech Republic

zstrmad@ef.jcu.cz.

ORCID: 0000-0002-4371-4252

Abstract. The development of small and medium-sized enterprises (SMEs) is at the center of interests of the relevant authorities in the European Union and national economies across Europe. The aim of this paper was to define and quantify important economic factors that shape the quality of business environment in the SME segment, and to compare their significance in Czech and the Slovak Republics. According to the defined aim a survey-based research was conducted with the enterprises of the SME segment. Responses from 312 enterprises in Czech Republic and 329 enterprises in Slovak Republic were obtained. The Z-score method was used to verify the scientific hypotheses. The research brought some interesting findings. Slovak entrepreneurs, despite

Received: December, 2018 1st Revision: April, 2019 Accepted: July, 2019

DOI: $10.14254 / 2071$ 8330.2019/12-2/14 
slower growth of GDP and income in Slovakia, better rated the importance of the Central bank in creating a stable business environment as well as the role commercial banks play in financing business needs. The results of this research support the perception that the quality of business environment is a complex consisting of both economic and non-economic factors. It was discovered that the overall rating of the business environment quality is lower than the rating of partial economic factors influencing it.

Keywords: business environment, quality of business environment, economic factors, monetary policy, commercial banks.

JEL Classification: L26

\section{INTRODUCTION}

Entrepreneurship is a significant part of the economic system of every country, having important effects on the growth of the entire society. Therefore, many authors put emphasis on the role of small and medium-sized enterprises (SMEs) in effective functioning of economic systems (Petrů et al., 2018; Kozubíková et al., 2017; Virglerova et al., 2017; Czarniewski, 2016; Dubravska et al., 2015; Antoniuk et al., 2018; Steger \& Stiglbauer, 2016).

Small and medium-sized enterprises are an important component of the economic system. It is a business segment that generates a significant share of added value, ensures a high share of total employment and contributes significantly to each country's export and innovation capacity.

These businesses have unique features that are determined by their nature and which also allow them to take a specific position in the economic system. On the one hand, SMEs generally have limited financial resources, which negatively affects corporate management, on the other hand, their "smallness" gives them a great deal of flexibility in responding to changes that occur in the economic system, respectively to engage in free market space that is uninteresting for large businesses (Chládková, 2015). According to Buno et al. (2015) it is an objective necessity the trend of forming a quality business environment in this segment.

This paper examines important economic factors behind the quality of business environment and quantifies their significance and intensity level in Czech Republic and Slovakia.

The structure of the research is the following: The theoretical part presents the research results regarding economic factors of the business environment quality. The second part defines the aim of the research, the methodology, and the description of the data used. The third part presents the results of the research and their discussion. The conclusion offers a final summary of the research.

\section{LITERATURE REVIEW}

The quality of the business environment is a key factor in countries' economic growth, as it plays an important role in the economy's competitiveness growth and future economic sustainability (Wruuck, 2015, Bunoa et al., 2015, Chládková, 2015; Domańska \& Zajkowski, 2018).

The business environment of SMEs is determined by a number of different factors that operate with varying intensity. Bunoa et al. (2015) state above all economic, political, institutional, legal, technological and cultural conditions. Chládková (2015) emphasizes the importance of legislative factors, institutional infrastructure and market operations. 
Economic factors (macroeconomic environment, monetary policy, SMEs ${ }^{\varsigma}$ access to external financing, and population consumption) play an important role in the context of shaping the business environment (Hudáková \& Masár, 2018; Suvittawat, 2019; Havierniková \& Kordoš, 2019).

The macroeconomic environment is one of the key factors affecting the business activity (Dragnic, 2014, Kadocsa \& Francsovics, 2011; Masood et al., 2019; Petrenko et al., 2019). More recently, Ipinnaiye, Dineen and Lenihan (2017) examined the drivers of SME performance by employing panel data and holistic multivariate modelling, and found that the firm growth is affected by macroeconomic environment both directly and indirectly. In this context, Bekeris (2012) emphasizes in particular the positive impact of a quality macroeconomic environment on the efficiency of SMEs.

Thai and Turkina (2014) conducted a survey based on the eclectic theory of entrepreneurship and concluded by finding that resources and abilities (including GDP per capita) negatively affect informal entrepreneurship. In addition, they did not find any significant influence of resources and abilities on formal entrepreneurship, which corresponds with Rusu and Roman's (2017) findings. In this regard, Autio and $\mathrm{Fu}(2015)$ went far in depth by examining the relation between economic institutions and firm entry into formal and informal entrepreneurship. They found positive effect of economic institutions on formal entrepreneurship and negative impact on informal ones.

Similarly, Grilli, Mrkajic and Latifi (2018) argue that venture capital activity is positively impacted by GDP growth. Thus, GDP growth can fosters venture capital activity, and consequently, entrepreneurship. These findings are consistent with Dvouletýs (2017) research which emphasizes the positive effect of GDP per capita on entrepreneurial activity. Nevertheless, Bosma et al. (2018) examined the opposite relationship (effect of entrepreneurship on economic growth). According to their analysis, as it can be expected, entrepreneurship positively affects economic growth. These results are consistent with findings by Acs, Estrin, Mickiewicz and Szerb (2018). Therefore, entrepreneurship is affected by the economic conditions including macroeconomic components.

Monetary policy may affect the quality of business environment (Kozmenko et al., 2016). Financial stability is an important factor that positively influences entrepreneurship (Bosma et al., 2018; Al-Smadi, 2018; Kozmenko \& Savchenko, 2011; Gedek et al., 2017). Kadocsa and Francsovics (2011) conducted a survey among Hungarian SMEs, exploring which macro and micro factors support or constrain the business activity. According to their survey, a reliable monetary policy was identified as the factor having the highest impact on the operation of businesses. Recently, the monetary policy applied in Hungary encourages businesses by expanding their activities. More than $60 \%$ of the interviewed SMEs stated that their business operations were affected by the monetary policy applied in Hungary.

Access to financing was identified as a significant predictor of entrepreneurship. Ardic, Mylenko and Saltane (2012) stressed that access to financing is a challenge for the SMEs. Ahmedova (2015) states that access to financing is the most important factor for SMEs to be competitive in the market. Enterprises with sufficient external resources are able to innovate and invest and hence be more successful in the competitive environment.

Krejcí et al. (2015) studied the factors that influence the success of SMEs in the Czech Republic, and concluded that financial indicator performs significantly in their success. However, Rusu and Roman's (2017) research supports a negative relationship between these factors, which is inconsistent with the expectations. Chowdhury, Audretsch and Belitski (2018) examined the relationship between institutions and quality entrepreneurship among emerged and emerging economies across the world. According to this study, credit in a country (measured as domestic credit to private sector by banks) positively affects the quality of entrepreneurship.

Credit or interest rate is found to be a significant predictor of firm performance. However, according to Yang's (2017) research, a growth in interest rate leads to a reduction in firm profit. According to Lim et 
al. (2010), entrepreneurial cognition influences business start-up. Among the institutional components that shape a business environment, the financial system was found to influence two components of entrepreneurial cognition, which are venture arrangements and willingness. Based on these discussions, business start-up and entrepreneurship activity is affected by the financial system of a country.

Tonoyan et al. (2010)found that when banks and other money lenders do not provide financing, using less paperwork, entrepreneurs usually engage in corrupted activities to get the financial support in transition countries. They also showed that due to complex rules and regulations, entrepreneurs in the transition countries engage in corruption to get their business activities. This was not found in the developed countries. They also found that extreme bureaucracy and complex bank loan paperwork drives entrepreneurs towards providing bribes and corrupted activities which is creating barriers for easy access to bank finance. The same situation is observed at the financial market as well (Missaoui et al., 2018).That's why there is a need in some measures against possible acts of corruption, for example, implementation of the Code of Ethics for SMEs (Antoniuk et al., 2018).

\section{Population consumption, changes in income and the structure of consumer expenditure}

Autio and $\mathrm{Fu}$ (2015) considered in their study the population growth as a possible predictor of firm entry. They found a significant positive association between them. Therefore, an increase in population led to a high rate of firm entry into the market. Furthermore, their study demonstrated a negative association between purchasing power parity and formal entrepreneurship and a positive influence of purchasing power parity on informal entrepreneurship. Thus, an association between purchasing power parity in a country and entrepreneurship can be assumed. Chowdhury et al. (2018) included population in a country as an independent variable to explain the quantity and quality of entrepreneurship among developed and developing counties. They found a negative association between quality of entrepreneurship and population. In this research, population was measured as the percentage of 15-64 year olds of the total population.

Moreover, some studies paid attention to the age distributions of the population, households' income, and consumer behavior, as part of the economic factors which may influence the quality of the business environment. Having a good relationship with the customers is considered by entrepreneurs as the most powerful component affecting their operations (Kadocsa \& Francsovics, 2011). The age distribution of the population and income were found as such factors by Grosanu and Bota-Avram (2015). Therefore, population consumption, changes in income and the structure of consumer expenditure might influence business start-up and entrepreneurial activity.

Dragnic (2014) emphasizes the great impact of the macroeconomic environment on the functioning of SMEs. This author also presents other interesting results of his research. He found that a high lack of demand for products and services had a negative effect on the growth of SMEs. The paper shows that SMEs faced high competition from unregistered SMEs which was creating a problem for SMEs to sell products to their target customers.

\section{AIM, METHODOLOGY AND DATA}

The aim of this paper was to define and quantify important economic factors that shape the quality of business environment in the SME segment, and compare their significance in the Czech and the Slovak Republic.

In regards to the defined aim, a survey-based research was conducted with enterprises operating in the SME segment. 312 enterprises in CR and 329 enterprises in SR were approached during this research. 
Data collection took place in 2018. The method of random choice using the "Randbetween" mathematical function was used to select enterprises from the "Albertína" database comprising enterprises in the Czech Republic. Slovak enterprises were randomly selected from the "Cribis" database containing the list of enterprises, organizations, and entrepreneurs. The enterprises were approached via email asking them to fill out the online questionnaire. The questionnaire was intended for business owners or top management (hereinafter entrepreneurs).

Four groups of economic factors were defined within the research, using the following statements:

Economic factors: (EF)

EF1: Macroeconomic environment

EF11: I consider the macroeconomic environment of my country to be favorable for doing business.

EF12: The state of macroeconomic environment of my country supports starting a business.

EF13: The present macroeconomic environment supports enterprises' innovation activities.

EF14: The present level of basic macroeconomic factors (GDP, employment, inflation) supports business and creates interesting business opportunities.

EF2: Monetary policy and interest rates

EF21: The Central Bank's monetary policy has a positive impact on the business environment.

EF22: Banks' interest rates have a positive impact on the business environment.

EF23: Banks' interest rates have a positive impact on enterprises' innovation activities.

EF24: The Central Bank's monetary policy stabilizes the business environment.

EF3: Financing enterprises

EF31: Enterprises have easy access to bank loans.

EF32: Banks' credit conditions for entrepreneurs are acceptable.

EF33: The cost of loans for enterprises is acceptable.

EF34: Banks have a positive impact on the quality of the business environment.

EF4 Population consumption, changes in income and the structure of consumer expenditure

EF41: The growing consumer consumption positively influences the quality of the business environment.

EF42: People can afford to buy more products and services.

EF43: The growing consumer consumption positively impacts my business.

EF44: People purchase more, compared to the past.

The quality of business environment was evaluated using the following statement:

QBE1: The business environment of my country is of good quality and convenient for starting a business.

In developing this paper, five scientific hypotheses were established:

H1: There are statistically significant differences in the evaluation of the macroeconomic environment by Czech and Slovak enterprises.

$\mathrm{H} 2$ : There are statistically significant differences in the evaluation of the monetary policy by Czech and Slovak enterprises.

H3: There are statistically significant differences in the evaluation of financing by Czech and Slovak enterprises.

H4: There are statistically significant differences in the evaluation of population consumption by Czech and Slovak enterprises.

H5: There are statistically significant differences in the evaluation of the quality of the business environment by Czech and Slovak enterprises.

To evaluate H1, H2, H3, H4, and H5, the method of Z score was used. Statistically significant differences between the positive answers of Czech and Slovak respondents were compared through 
Pearson statistics at the significance level of $5 \%$. If the calculated p-value was lower than $5 \%$, the null hypothesis was rejected, and the alternative hypothesis was adopted. The calculations were made through the free software available at http://www.socscistatistics.com/tests/ztest/Default2.aspx.

\section{EMPIRICAL RESULTS AND DISCUSSION}

The research results are listed in the tables below.

Table 1

Evaluation of EF1: Macroeconomic environment

\begin{tabular}{|l|c|c|c|}
\hline Factor & $\begin{array}{c}\text { Number of positive answers CR/\% } \\
\text { out of the total number of } 312\end{array}$ & $\begin{array}{c}\text { Number of positive answers SR/\% } \\
\text { out of the total number of 329 }\end{array}$ & $\begin{array}{c}\text { Z-score: p-value } \\
\text { CR/SR }\end{array}$ \\
\hline EF11 & $101 / \mathbf{3 2}$ & $89 / 27$ & 0.142 \\
\hline EF12 & $77 / \mathbf{2 5}$ & $81 / \mathbf{2 5}$ & 0.984 \\
\hline EF13 & $81 / 26$ & $93 / 28$ & 0.435 \\
\hline EF14 & $99 / 32$ & $125 / \mathbf{3 8}$ & 0.097 \\
\hline
\end{tabular}

Source: Authors' results

$32 \%$ of respondents in the Czech Republic and 27\% of respondents in Slovakia agreed with the statement that the state of macroeconomic environment is favorable for doing business. (EF11). Equally in both countries, $25 \%$ of respondents agreed with the statement that the macroeconomic environment supports starting a business (EF12).26\% of respondents in the Czech Republic and $28 \%$ of respondents in Slovakia agreed with the statement that macroeconomic environment supports enterprises' innovation activities (EF13). 32\% of respondents in the Czech Republic and 38\% of respondents in Slovakia agreed with the statement that the current level of basic macroeconomic factors (GDP, employment, inflation) supports business and creates interesting business opportunities.

The results of the testing criterion p-value $(0.142 ; 0.984 ; 0.435 ; 0.097)$ confirm that there are no statistically significant differences between respondents' answers in the two countries.

H1 was not confirmed.

Table 2

Evaluation of EF2: Monetary policy and interest rates

\begin{tabular}{|l|c|c|c|}
\hline Factor & $\begin{array}{c}\text { Number of positive answers CR/\% } \\
\text { out of the total number of } 312\end{array}$ & $\begin{array}{c}\text { Number of positive answers SR/\% } \\
\text { out of the total number of 329 }\end{array}$ & $\begin{array}{c}\text { Z-score: p-value } \\
\text { CR/SR }\end{array}$ \\
\hline EF21 & $77 / 25$ & $111 / \mathbf{3 4}$ & $\mathbf{0 . 0 1 2}$ \\
\hline EF22 & $107 / \mathbf{3 4}$ & $134 / \mathbf{4 1}$ & 0.093 \\
\hline EF23 & $84 / 27$ & $119 / 36$ & $\mathbf{0 . 0 1 1}$ \\
\hline EF24 & $75 / \mathbf{2 4}$ & $114 / 35$ & $\mathbf{0 . 0 0 3}$ \\
\hline
\end{tabular}

Source: Authors' results

Based on the research results, it can be said that only $25 \%$ of entrepreneurs in the Czech Republic and $34 \%$ in Slovakia agreed with the statement that the Central bank's monetary policy has a positive impact on the business environment (EF21). 34\% of entrepreneurs in the Czech Republic and 41\% of entrepreneurs in Slovakia agreed with the statement that banks ${ }^{6}$ interest rates have a positive impact on business environment (EF22). 27\% of entrepreneurs in the Czech Republic and 36\% of entrepreneurs in Slovakia agreed with the statement that banks' interest rates have a positive impact on enterprises' 
innovation activities (EF23). Only 24\% of entrepreneurs in the Czech Republic and 35\% of entrepreneurs in Slovakia thought that the Central Bank's monetary policy stabilizes the business environment (EF24).

H2 was confirmed. The results of the testing criterion p-value $(0.012 ; 0.011 ; 0.003)$ confirm that there are statistically significant differences in entrepreneurs' answers. Slovak entrepreneurs rated the impact of the Central bank's monetary policy on business environment and its stability better than their Czech counterparts, and also more positively evaluated the impact of interest rates on business environment.

Table 3

Evaluation of EF3: Financing of enterprises

\begin{tabular}{|l|c|c|c|}
\hline Factor & $\begin{array}{c}\text { Number of positive answers CR/\% } \\
\text { out of the total number of 312 }\end{array}$ & $\begin{array}{c}\text { Number of positive answers SR/\% } \\
\text { out of the total number of 329 }\end{array}$ & $\begin{array}{c}\text { Z-score: p-value } \\
\text { CR/SR }\end{array}$ \\
\hline EF31 & $141 / \mathbf{4 5}$ & $163 / \mathbf{5 0}$ & 0.271 \\
\hline EF32 & $111 / 36$ & $127 / 39$ & 0.429 \\
\hline EF33 & $114 / 37$ & $147 / 45$ & $\mathbf{0 . 0 3 6}$ \\
\hline EF34 & $75 / \mathbf{2 4}$ & $115 / \mathbf{3 5}$ & $\mathbf{0 . 0 0 3}$ \\
\hline
\end{tabular}

Source: Authors' results

$45 \%$ of entrepreneurs in the Czech Republic and 50\% of entrepreneurs in Slovakia agreed with the statement that enterprises have easy access to bank loans (EF31). Based on the research results, it can be said that over one third of entrepreneurs in both countries agreed with the statement that banks' credit conditions for entrepreneurs are acceptable (EF32), specifically 36\% of entrepreneurs in the Czech Republic and 39\% in Slovakia. The cost of loans was acceptable for 37\% of Czech and 45\% Slovak entrepreneurs (EF33). 24\% of Czech entrepreneurs and 35\% Slovak entrepreneurs think that commercial banks have a positive impact on the quality of the business environment (EF34).

H3 was partially confirmed. The results of the testing criterion p-value $(0.036 ; 0.003)$ confirm that there are statistically significant differences in entrepreneurs' answers. Slovak entrepreneurs more positively evaluated the impact of commercial banks on the quality of business environment and their monetary policy than Czech entrepreneurs.

Table 4

Evaluation of EF4: Population consumption, changes in income and the structure of consumer expenditures

\begin{tabular}{|l|c|c|c|}
\hline Factor & $\begin{array}{c}\text { Number of positive answers CR/\% } \\
\text { out of the total number of 312 }\end{array}$ & $\begin{array}{c}\text { Number of positive answers SR/\% } \\
\text { out of the total number of 329 }\end{array}$ & $\begin{array}{c}\text { Z-score: p-value } \\
\text { CR/SR }\end{array}$ \\
\hline EF41 & $206 / 66$ & $214 / 65$ & 0.795 \\
\hline EF42 & $258 / \mathbf{8 3}$ & $270 / 82$ & 0.834 \\
\hline EF43 & $197 / \mathbf{6 3}$ & $220 / \mathbf{6 7}$ & 0.322 \\
\hline EF44 & $252 / 81$ & $272 / \mathbf{8 3}$ & 0.535 \\
\hline
\end{tabular}

Source: Authors' results

Entrepreneurs in both countries highly agreed that factor EF4 (population consumption) has a positive impact on the quality of business environment. $66 \%$ of entrepreneurs in the Czech Republic and $65 \%$ of entrepreneurs in Slovakia agreed with the statement that the growing consumer consumption positively influences the quality of the business environment (EF41).Factor EF42 received the highest rate 
of positive answers. $83 \%$ of Czech and $82 \%$ of Slovak entrepreneurs agreed with the statement that people can purchase more products and services which has a positive impact on their business activities.

63\% of entrepreneurs in the Czech Republic and 67\% of entrepreneurs in Slovakia agreed with the statement that the growing consumer consumption positively impacts their business (EF43).Entrepreneurs also highly agreed with the fact that people purchase more than in the past (EF44).

The results of the testing criterion $\mathrm{p}$-value $(0.795 ; 0.834 ; 0.322 ; 0.535)$ confirm that there are no statistically significant differences in the answers of both countries' entrepreneurs.

H4 was not confirmed.

Table 5

Evaluation of the quality of business environment in CR and SR

\begin{tabular}{|c|c|c|}
\hline Factor & $\begin{array}{c}\text { Positive answer ratio expressed by } \\
\text { index in CR/SR }\end{array}$ & $\begin{array}{c}\text { Z-score } \\
\text { p-value }\end{array}$ \\
\hline QBE1 & $0.253 / 0.195$ & 0.075 \\
\hline
\end{tabular}

Source: Authors' results

The results in Table 5 can be interpreted as follows: $25 \%$ of Czech and $20 \%$ of Slovak entrepreneurs agreed with the statement that the business environment in their respective countries is of good quality and suitable for doing business. There are no statistically significant differences in the evaluation of the business environment.

H5 was not confirmed.

The research results brought some interesting findings.

Despite the current positive economic development, entrepreneurs in both countries gave the impact of the macroeconomic environment on shaping the quality of business environment a less positive rating, as the agreement rate with the suggested statements varied between 25 and $38 \%$ (the average agreement rate was 29\% in the Czech Republic and 30\% in Slovakia). This means that approximately one third of entrepreneurs in both countries positively evaluated the impact of macroeconomic environment on shaping the quality of business environment.

Slovak entrepreneurs were more positive than their Czech counterparts in evaluating the impact of Central bank's monetary policy on the business environment and its stability, as well as the impact of Central bank's interest rates on the business environment.

Slovak entrepreneurs also more positively viewed the impact of commercial banks and their monetary policy on the quality of business environment.

Entrepreneurs highly agreed with the statement that growing population consumption in both countries supports the quality of business environment. The agreement rate with respective statements varied between 63 and 83\% (the average agreement rate was $73 \%$ in the Czech Republic and $74 \%$ in Slovakia).

The results of our research are largely compatible with the generally known results of assessing the competitiveness of countries and also the quality of the business environment. The Czech Republic is around the 30th place in the competitive assessment in the world. It achieves the best results in assessing the macroeconomic environment, education and maturity of financial markets. On the other hand, the Czech Republic lags behind in terms of innovation and the quality of the business environment (Investiční web, 2016). The Slovakia is much worse because it was 59th in the world in 2017. Slovak entrepreneurs 
have long criticized corruption environment, excessive bureaucracy, labor market and employee education (Slovak Business Alliance, 2017).

There are some interesting trends in the area of monetary policy in the context of current economic development. For explanation: while Česká národní banka (ČNB) is an independent monetary institution, Národná banka Slovenska (NBS) has been a part of the Eurosystem since January 1st, 2009, and together with the European Central Bank (ECB) and other central banks within the Eurozone aims primarily at maintaining the monetary stability within the Eurozone.

There was a higher GDP growth in the Czech Republic (currently 4.5\%) than in Slovakia (4\%), while the basic interest rate of $\check{C} \mathrm{NB}$ is $0.75 \%$ and $0 \%$ in the ECB. In both countries, there is an undesirable trend of growth in wages compared to the growth of productivity of labor. Increase of wages in the Czech Republic was 7\% in 2018 and approximately 5.5\% in Slovakia. It seems at the moment that the CNB react appropriately to the current macroeconomic development within the monetary policy (it plans an increase of the basic interest rate in order to prevent economic overheating), however, these efforts are not compatible with entrepreneurs' interests.

The situation with financing SMEs has improved considerably. In a research done in 2013 (Belas et al., 2014), entrepreneurs rated the financing offered by banks rather negatively. As an example, only $3 \%$ of Slovak entrepreneurs agreed with the statement that banks fully accept their needs and strive to accommodate them, 20\% said that banks behave adequately, and 37\% viewed banks' criteria for granting loans as too strict. The situation in the Czech Republic was better, as up to 39\% of entrepreneurs thought that banks acted adequately. In another research dated 2017 (Belás et al., 2017), there is a visible shift in entrepreneurs' notions. Up to $67 \%$ of Czech entrepreneurs claimed that banks help them in achieving financial goals, and $42 \%$ of them agreed with the statement that banks' credit conditions are favorable.

The authors also state that only $36 \%$ of Czech entrepreneurs agreed with the statement that banks credit conditions are transparent, while only $27 \%$ of them agreed with the claim that costs of loans are favorable.

This research confirmed the assumption that consumer expenditure is higher (it was more than $80 \%$ of entrepreneurs in both countries), and also confirmed its positive impact on business activities (claimed by more than $60 \%$ of entrepreneurs in both countries). The research results are comparable with other institutions ${ }^{6}$ data. According to the data from Svaz obchodu a cestovního ruchu (2018), household expenses in the Czech Republic increased quarterly in 2017 faster than the country's economy. While quarterly household expenses grew as follows: $+4 \% /+3.6 \% /+3.7 \% /+3 \%$, the GDP grew slower: + $3.8 \% /+2.8 \% /+1.8 \% /+1.8 \%$. This trend also showed in retail sales. According to date from Český statistický úrad (2018), retail sales in the Czech Republic grew by 5.6\% in 2017 compared to 2016. This growth was even higher in Slovakia. In 2017, sales in retail increased by 8.4\% compared to 2016.

The research results support the perception that the quality of business environment is a complex consisting of both economic and non-economic factors (e.g. Bunoa et al., 2015; Chládková, 2015; and others). It was discovered that the overall rating of the quality of business environment is lower than the rating of partial economic factors influencing it. E.g. the average ratio of positive answers in the Czech Republic was as follows: $\mathrm{EF} 1=29 \%$; EF2 $=28 \%$; EF3 $=35 \%$; EF4 $=73 \%$, and $25 \%$ for the quality of business environment. This trend was even stronger in Slovakia where the values of partial economic factors were the following: $\mathrm{EF} 1=29 \%$; $\mathrm{EF} 2=36 \%$; $\mathrm{EF} 3=42 \%$; $\mathrm{EF} 4=74 \%$, while the positive rating of the quality of business environment reached $19 \%$.

Therefore, it can be assumed that other factors, especially political (legislative environment, bureaucracy, state regulation and support of entrepreneurship) significantly determine the perception of the quality of business environment. 


\section{CONCLUSION}

The aim of the paper was to define and quantify important economic factors that shape the quality of business environment in the SME segment, and compare their significance in the Czech and the Slovak Republic.

The quality of the business environment is a complex system of various factors both within and outside the economic area. These factors cannot be easily and conclusively quantified, therefore, it can be assumed that the results depend to a certain degree on the research setup.

In this context, it is more appropriate to imply trends rather than present conclusive results.

The quality of business environment is determined not only by economic factors, but also by political, institutional, legal, and cultural factors that can either support the positive view of the quality of business environment, or cause its negative perception. This research reveals the need to pay closer attention to the shaping of non-economic factors.

The research brought interesting findings. The own currency policy serving primarily as a protection of exporters, is viewed by entrepreneurs rather negatively. It can be assumed that entrepreneurs prefer the advantages of an integral unit to the advantages of their own currency. In this research, Slovak entrepreneurs were more positive when rating the importance of the Central bank in creating a stable business environment and the impact of interest rates on the quality of business environment, compared to Czech entrepreneurs.

One of the positive findings was the fact that a favorable economic environment reduces the important barrier of external financing for SMEs via bank loans.

The research has its limitations, but also brought interesting findings and a potential inspiration for further research of the quality of the business environment in the SME segment.

The next research shall examine the impact of political, technological, and social factors on the quality of business environment.

\section{REFERENCES}

Acs, Z. J., Estrin, S., Mickiewicz, T., \& Szerb, L. (2018). Entrepreneurship, institutional economics, and economic growth: an ecosystem perspective. Small Business Economics, 51(2), 501-514. https://doi.org/10.1007/s11187018-0013-9

Ahmedova, S. (2015). Factors for increasing competitiveness of small and medium-sized enterprises (SMEs) in Bulgaria. Procedia-Social and Behavioral Sciences, 195, 1104-1112.

Al-Smadi, Mohammad O. (2018). The role of financial inclusion in financial stability: lesson from Jordan. Banks and Bank Systems, 13(4), 31-39. http://dx.doi.org/10.21511/bbs.13(4).2018.03

Antoniuk, L., Britchenko, I., Polishchuk, Ye., Rudyk, N., Sybirianska, Y., \& Machashchik, P. (2018). Code of ethics for SMEs: Substantiating the necessity and willingness to implement in Ukraine. Problems and Perspectives in Management, 16(3), 150-162. http://dx.doi.org/10.21511/ppm.16(3).2018.12

Ardic, O. P., Mylenko, N., \& Saltane, V. (2012). Access to Finance by Small and Medium Enterprises: A CrossCountry Analysis with a New Data Set. Pacific Economic Review, 17(4), 491-513. https://doi.org/10.1111/j.1468-0106.2012.00596.x

Autio, E., \& Fu, K. (2015). Economic and political institutions and entry into formal and informal entrepreneurship. Asia Pacific Journal of Management, 32(1), 67-94. https:// doi.org/10.1007/s10490-014-9381-0

Bekeris, R. (2012). The impact of macro-economic indicators upon SME's profitability. Ekonomika, 91(3), 117-128.

Belás, J., Dvorský, J., Čepel, M., Kotásková, A. (2017). Evaluation of commercial banks’ approach to SME segment entrepreneurs. Case Study from the Czech Republic. Proceedings of ICFE 2017-The 4 ${ }^{\text {th }}$ International ConferenceonFinance and Economics. 
Belás, J., Macháček, J., Bartoš, P., Hlawiczka, R., Hudáková, M. (2014). Business Risks and the Level of Entrepreneurial Optimism among SME in the Czech and Slovak Republic. Journal of Competitiveness, Vol. 6, Issue 2, pp. 30- 41.

Bosma, N., Content, J., Sanders, M., \& Stam, E. (2018). Institutions, entrepreneurship, and economic growth in Europe. Small Business Economics, 51(2), 483-499. https://doi.org/10.1007/s11187-018-0012-x

Bunoa, M., Nadanyiova, M., \& Hraskova, D. (2015). The comparison of the quality of business environment in the countries of Visegrad group. Procedia Economics and Finance, 26, 423-430.

Český statistický úřad. (2018). Maloobchod-prosinec 2017. Retrieved from www.czso.cz/csu/czso/cri/maloobchodprosinec-2017

Chládková, H. (2015). Selected approaches to the business environment evaluation. Acta Universitatis Agriculturae et Silviculturae Mendelianae Brunensis, 63(2), 513-523. http://dx.doi.org/10.11118/actaun201563020515

Chowdhury, F., Audretsch, D. B., \& Belitski, M. (2018). Institutions and Entrepreneurship Quality. Entrepreneurship Theory and Practice, 1-31. https://doi.org/10.1177/1042258718780431

Czarniewski, S. (2016). Small and Medium-Sized Enterprises in the Context of Innovation and Entrepreneurship in the Economy. Polish Journal of Management Studies, 13(1), 30-39.

Domańska, A., \& Zajkowski, R. (2018). Influence of state participation on business conditions and enterpreneuship in the EU countries of the former eastern bloc. Financial Internet Quarterly „e-Finanse”, 14(2), 9-17. doi: 10.2478/ fiqf-2018-0008

Dragnic, D. (2014). Impact of internal and external factors on the performance of fast-growing small and medium businesses. Management: Journal of Contemporary Management Issues, 19(1), 119-159.

Dubravska, M., Mura, L., Kotulic, R., \&Novotny, J. (2015). Internationalization of Entrepreneurship - Motivating Factors: Case Study of the Slovak Republic. Acta Polytechnica Hungarica, 12(5), 121-133.

Dvouletý, O. (2017). Determinants of Nordic entrepreneurship. Journal of Small Business and Enterprise Development, 24(1), 12-33. https://doi.org/10.1108/JSBED-07-2016-0104

Gedek, S., Misiak, T., \& Mentel, G. (2017). Changes in GDP and the Employment and Unemployment in the European Union. Transformations in Business \& Economics, 16(3C) (42C), 42-59.

Grilli, L., Mrkajic, B., \& Latifi, G. (2018). Venture capital in Europe: social capital, formal institutions and mediation effects. Small Business Economics, 51(2), 393-410. https://doi.org/10.1007/s11187-018-0007-7

Grosanu, A., \& Bota-Avram, C. (2015). The influence of country-level governance on business environment and entrepreneurship: A global perspective. Amfiteatru Economic, 17(38), 60.

Havierniková, K., \& Kordoš, M. (2019). Selected risks perceived by SMEs related to sustainable entrepreneurship in case of engagement into cluster cooperation. Entrepreneurship and Sustainability Issues, 6(4), 1680-1693. http://doi.org/10.9770/jesi.2019.6.4(9)

Hudáková, M., \& Masár, M. (2018). The Assessment of Key Business Risks for SMEs in Slovakia and Their Comparison with other EU Countries. Entrepreneurial Business and Economics Review, 6(4), 145-160. https://doi.org/10.15678/EBER.2018.060408

Investiční web. (2016). Světový žebříček konkurenceschopnosti vede Švýcarsko, Česko je 31. Co nám chybí, a v čem jsme naopak (relativně) silní? Available from http://www.investicniweb.cz/news-2016-9-28-zebricekkonkurenceschopnosti-vede-svycarsko-cr-je-31/

Ipinnaiye, O., Dineen, D., \& Lenihan, H. (2017). Drivers of SME performance: a holistic and multivariate approach. Small Business Economics, 48(4), 883-911. https://doi.org/10.1007/s11187-016-9819-5

Kadocsa, G., \& Francsovics, A. (2011). Macro and micro economic factors of small enterprise competitiveness. Acta Polytechnica Hungarica, 8(1), 23-40.

Kozmenko, S., Savchenko,T., \&Zakutniaia,A.(2016). The impact of monetary policy transparency on inflation: the case of Ukraine. Banks and Bank Systems, 11(4), 82-89. http://dx.doi.org/10.21511/bbs.11(4).2016.08. 
Kozmenko,S.,\&Savchenko,T.(2011). Countercyclical monetary policy in major economies of the Commonwealth of Independent States. Investment Management and Financial Innovations, 8(4), 8-19.

Kozubíková, L., Homolka, L., \& Kristalas, D. (2017).The Effect of Business Environment and Entrepreneurs' Gender on Perception of Financial Risk in the SMEs Sector. Journal of Competitiveness, 9(1), 36-50. Available from: http:/ /dx.doi.org 10.7441/joc.2017.01.03

Krejcí, M., Strielkowski, W., \& Čabelková, I. (2015). Factors that influence the success of small and medium enterprises in ICT: a case study from the Czech Republic. Verslas: Teorija Ir Praktika, 16(3), 304-315. https://doi.org/10.3846/btp.2015.521

Lim, D. S. K., Morse, E. A., Mitchell, R. K., \& Seawright, K. K. (2010). Institutional Environment and Entrepreneurial Cognitions: A Comparative Business Systems Perspective. Entrepreneurship Theory and Practice, 34(3), 491-516. https://doi.org/10.1111/j.1540-6520.2010.00384.x

Masood, O., Tvaronavičienè, M., Javaria, K. (2019).Impact of oil prices on stock return: evidence from G7 countries. Insights into Regional Development, 1(2), 129-137. https://doi.org/10.9770/ird.2019.1.2(4)

Missaoui, I., Brahmi,M., \& BenRajeb, J. (2018). Quantitative relationship between corruption and development of the Tunisian stock market. Public and Municipal Finance, 7(2), 39-47. http://dx.doi.org/10.21511/pmf.07(2).2018.04

Petrenko, Y., Vechkinzova, E., \& Antonov, V. (2019).Transition from the industrial clusters to the smart specialization of the regions in Kazakhstan. Insights into Regional Development, 1(2), 118128. https://doi.org/10.9770/ird.2019.1.2(3)

Petrů, N., Havlíček, K., \& Tomášková, A. (2018). Comparison of Marketing Vitality of Family and Non Family Companies doing Business in the Czech Republic. Economics and Sociology, 11(2), 138-156. doi:10.14254/2071789X.2018/11-2/10

Podnikatel’ská Aliancia Slovenska (2017). Slovensko sa posunulo v globálnom rebríčku, pomohlo viac leteckých liniek, mobilov, rýchlejší internet a zhoršenie iných. Available from: http://alianciapas.sk/category/pravidelneaktivity/ sprava oglobalnej konkurencieschopnosti/

Poštová banka. (2018). Tržby slovenských maloobchodníkov v roku 2017. Available at:www.postovabanka.sk/novinky/analyzy-trhu/zaujalo-nas/trzby-slovenskych-maloobchodnikov-v-roku2017/

Rusu, V., \& Roman, A. (2017). Entrepreneurial Activity in the EU: An Empirical Evaluation of Its Determinants. Sustainability, 9(12), 1679. https://doi.org/10.3390/su9101679

Steger,T.,\&Stiglbauer,M. (2016). The German corporate governance code and its adoption by listed SMEs - just another 'Procrustes bed'?. Problems and Perspectives in Management, 14(3-2), 494-503. http://dx.doi.org/10.21511/ppm.14(3-2).2016.05

Suvittawat, A. (2019). Passions and enthusiasm of small and medium enterprises (SMEs): A case study of Nakorn Ratchasima province, Thailand. Entrepreneurship and Sustainability Issues, 6(3), 1169-1179. http://doi.org/10.9770/jesi.2019.6.3(22)

Svaz obchodu a cestovního ruchu. (2018). Výdaje českých domácnosti: spotreba roste a diferenciace pokračuje. Available at: http://www.socr.cz/clanek/vydaje-ceskych-domacnosti-spotreba-roste-a-diferenciace-pokracuje/

Thai, M. T. T., \& Turkina, E. (2014). Macro-level determinants of formal entrepreneurship versus informal entrepreneurship. Journal of Business Venturing, 29(4), 490-510. https://doi.org/10.1016/J.JBUSVENT.2013.07.005

Tonoyan, V., Strohmeyer, R., Habib, M., \& Perlitz, M. (2010). Corruption and entrepreneurship: How formal and informal institutions shape small firm behaviour in transition and mature market economics. Entrepreneurship theory and practice, 803-832.

Virglerova, Z., Homolka, L., Smrčka, L., Lazányi, K., \& Klieštik, T. (2017). Key determinants of the quality of business environment of SMEs in the Czech Republic. E \& M Ekonomie a Management, 20(2), 87-100. http://doi.org./10.15240/tul/001/2017-2-007 
Wruuck, P. (2015). The business environment in the Eurozone. Deutsche Bank AG Deutsche Bank Research Frankfurt am Main Germany. Available at: https://www.dbresearch.com/PROD/DBR_INTERNET_EN-PROD/ PROD 000000

00379559/The_business_environment_in_the_eurozone\%3A_Why_it_i.pdfhttp://www.socscistatistics.com /tests/ztest/Default2.aspx.

Yang, J. S. (2017). The governance environment and innovative SMEs. Small Business Economics, 48(3), 525-541. 